\title{
Building alliances for the global governance of migration and health
}

\author{
Health governance has an important role in dealing with global migration, argue Jo Vearey and \\ colleagues
}

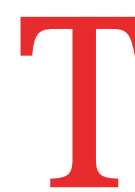

he term "migrant" has become sharply politicised and misused by political leaders to support nationalistic, populist agendas that tend to exclude and dehumanise international migrants. Migrants are portrayed as unlawful and violent, as a threat to domestic jobs, and as a burden on the health and welfare systems of host nations. ${ }^{1}$ Consequently, people moving across international borders often face xenophobic and racist treatment. Undocumented migrants, refugees, and asylum seekers are often perceived as undeserving, thereby justifying exclusion from formal societal structures and systems.

Public anxiety about threats to livelihood, society, and moral decency are providing nation states, particularly high income states, with ammunition to implement increasingly restrictive and punitive immigration regimes. These include building walls and detention centres, separating families, and refusing to accept individuals fleeing war. These approaches are clearly unworkable: they make mobility more dangerous, negatively affect health and wellbeing, and threaten the lives of people trying to cross international borders. ${ }^{23}$ This was

\section{KEY MESSAGES}

- Universal health coverage will not be attained if migration is not integrated into existing health responses and if health is not integrated into existing migration responses

- The governance of migration and health is an issue of state sovereignty that questions the role of global migration and health governance initiatives

- Building alliances across sectors can support effective migration aware governance responses to migration and health

- A "migration and health in all policies" approach to the governance of migration and health requires capacity building within core sectors tragically shown in June 2018 when deaths peaked in the central Mediterranean after search and rescue boats stopped operating because Malta and Italy closed their ports to rescue vessels as part of anti-immigration policies. ${ }^{45}$ Policies such as these have not been shown to reduce immigration, indicating poor use of taxpayers' funds, which may have negative consequences for the social and economic potential associated with healthy migration. ${ }^{6}$

\section{Migration and health governance}

Health governance has an important part to play in managing the challenges faced by countries dealing with international migration. Health governance is the whole-of-government and whole-of-society approaches that governments and others use to steer countries and communities in the pursuit of health and wellbeing. Effective governance requires alliance building with constituencies who are ultimately responsible for tackling health and migration: these include regional economic communities; national and local governments (including ministries of health, social security, international affairs, defence, home affairs); civil society and migrant led advocacy and service groups; humanitarian organisations; international organisations; the research community; the private sector; and funding agencies. Governance should take into account existing work on internal displacement, helping to build on lessons learnt from disaster risk reduction, protection, economic modelling, and urban resilience perspectives.

Despite some examples of good practice, there is a long way to go before evidence informed, respectful, ethical, and justice driven responses are developed to ensure that the diverse processes of migration and their complex associations with health are effectively governed. While we support previous calls to action ${ }^{7-11}$ and recognise opportunities for migration and health to be integrated into existing and new multilevel governance mechanisms, we have identified four concerns that are limiting progress which should be tackled to improve health for all migrants.

Firstly, while there are roughly 258 million international migrants, including migrant workers, refugees, and asylum seekers, it is estimated that at least three times that number, roughly 763 million, move within their countries of birth. ${ }^{12}$ This includes those moving in search of improved livelihood opportunities as well as the 40 million people internally displaced by armed conflict, generalised violence, and human rights violations. ${ }^{13}$ Many of those internally displaced will subsequently be forced to migrate across borders. Despite the evidence highlighting the need to respond to internal migration and health, internal population movements are mostly ignored by efforts to develop effective governance responses to migration and health.

Secondly, global discussions on migration and health tend to focus on high income receiving countries, particularly those dealing with the European migration crisis. ${ }^{1415}$ This risks further stigmatising certain governments, geographies, and people while ignoring others. ${ }^{15}$ Low and middle income countries have taken on disproportionate burdens in housing and caring for international migrant populations, and many offer good practice examples for governing migration and health that have been overlooked. ${ }^{1}$ Engaging with these experiences will be critical in supporting a more balanced view of migration trends globally.

Thirdly, despite popular opinion, the governance of migration and health is not simply an issue of global health security and disease control. Governance responses to migration and health must ensure that the global health security agenda is not misappropriated by the increasingly security focused response to international migration. Should these domains become blurred, punitive disease control measures, including screening at borders, could be used to justify further restricting movement between and within states. ${ }^{16-18}$

The persistent trope of a migrant as an infectious outsider who threatens the wider 
community continues to gain public and political currency. ${ }^{1619}$ This is despite the increasing recognition that the relation between migration and infectious disease is not as straightforward as is often assumed and that there is no systematic association between migration and the importation of infectious diseases. ${ }^{711}$ Rather, the migration process itself can make migrants more vulnerable to infectious diseases, with a low risk of migrants transmitting communicable diseases to the general population. ${ }^{1120}$ Migrants may be disproportionately affected by preventable infectious diseases as a result of the multiple structural factors that can increase exposure to infectious diseases before, during, and after their journey and limit the uptake of vaccines and prophylactics, in addition to their movement from areas of high to low infectious disease prevalence. $^{20}$

Finally, and most importantly, migration and health governance is an issue of state sovereignty. Recognition of this by global migration and health governance initiatives, and their associated non-binding frameworks, is key to developing effective responses to migration and health. ${ }^{21}$ Building solidarity in tackling public health challenges of migration, including integrating responses to migration within health systems, will require engaging with the tensions associated with sovereignty and the nation state. To this end, the research community, through meaningful partnerships and building alliances with states, need to show that developing, implementing, and monitoring effective governance responses to health and migration are a cost effective way to uphold their international human rights obligations, while at the same time ensuring that the social and economic development benefits of migration can be realised at the national level. $^{22}$

\section{Building alliances for effective governance of migration and health}

Alliance building ${ }^{23}$ can support action towards the effective governance of migration and health and benefit both the global health and international migration governance domains. An alliance building approach, driven by the health sector of nation states rather than through a top-down international global health governance approach, could support the development of effective migration aware responses to migration and health. ${ }^{7}$ Drawing from the principles associated with a Health in All Policies approach, ${ }^{24}$ a Migration and Health in all Policies approach for the governance of migration and health could assist in alliance building to support strategic opportunities for intervention at the national level. ${ }^{25}$ Key here is working to ensure that, firstly, health policies consider migration and, secondly, immigration policies consider health. While recognising the need for targeted migration and health interventions to tackle the needs of specific migrant groups-for example, in the case of communicable disease outbreaks or in refugee camps and detention settingsa Migration and Health in all Policies approach aims to facilitate the mainstreaming of migration into health governance and health into existing migration governance systems. This would deal with concerns associated with the development of migrant sensitive health programming, which could, albeit inadvertently, contribute to further stigmatising of migrant populations.

A central challenge, however, is that the field of migration and health is rarely a directly mandated or resourced focus area within either the health or the migration governance sectors, making the development and implementation of any action difficult. Opportunities for strategic intervention, premised on building alliances, need to be identified. This requires the mobilisation of financial resources as well as political will and technical capacity, and the raising awareness of the critical importance of responding to migration to achieve global health targets.

A collective, alliance based programme of action on migration and health that brings together civil society, practitioners, policy makers, and researchers is needed. A central "point-person" to drive and coordinate this process would need to be identified within central government; in different contexts, different focal persons may exist. Sri Lanka is a rare example of a country with a dedicated-and well documented-national migration and health policy process that can provide helpful insight for other countries. ${ }^{26}$ To support innovation and context specific alliance building, research is required to document and evaluate existing migration and health interventions and policies.

Crucially, there is a need to develop ways to future proof ${ }^{27}$ the global governance of migration and health: this is a contemporary governance priority for both the global health and migration sectors. If migration and health governance continues to be sidelined, it jeopardises action towards major global health targets, including those associated with the sustainable development goals, most notably that of universal health coverage. Two global compacts (international principles for good practice) were adopted in December 2018: one focuses on international migration and the other on refugees. These compacts provide opportunities for nation states to implement good governance approaches to tackle migration and health. Whether nation states choose a governance approach based on increasingly nationalistic discourses or an evidence informed approach to healthy migration remains to be seen. Developing a national scorecard on Migration and Health in all Policies, similar to the established Health in All Policies approach, ${ }^{25}$ could be an important step in holding nation states to account on their commitments both to universal health coverage and the sustainable development goals. To truly "leave no one behind" there must be a concerted global effort to build alliances to include migration and health in all policies.

We thank Kolitha Wickramage for his guidance in the conceptualisation of the paper and Paul Simpson for helpful comments on the first draft of the paper and editorial support. The Migration and Health in all Policies concept is under development, involving collaboration between JV, Charles Hui, and Kolitha Wickramage.

Contributors and sources: JV established the Migration and Health Project Southern Africa (maHp) and is vice-chair of the global Migration Health and Development Research Initiative (MHADRI) and director of the African Research Universities Alliance (ARUA) Centre of Excellence on Migration and Mobility hosted at the ACMS, Wits University. MO coordinates the UCL-Lancet Commission on Migration and Health and previously worked for Médecins sans Frontières and the World Health Organization. LG directs the World Health Organization Collaborating Center on Global Health Law, where he has worked closely with WHO on global health. CAB is a doctoral student who has spent several years studying and researching the health needs of migrants, and has a broad interest in access to healthcare for marginalised groups across Africa and Europe. PD has been working in migration health for over 12 years in multiple settings across Asia as well as the Americas, with a particular interest in public health response to large scale population displacement. JV conceptualised the paper and wrote the first draft. JV, MO, LG, PD, and CAB reviewed and contributed to the article. JV revised the manuscript based on helpful comments from three reviewers. All authors approved the final manuscript.

Competing interests: We have read and understood BMJ policy on declaration of interests and have no relevant interests to declare.

Provenance and peer review: Commissioned; externally peer reviewed.

This article is part of a series developed by The BMJ. the UN Migration Agency (IOM), and the Migration Health and Development Research Network (MHADRI). The article was commissioned by The BMJ, which retained full editorial control over external peer review editing, and publication of these articles. Open access fees for the initial articles in the series were funded by IOM and Bruyère Research Institute.

Jo Vearey, associate professor and director ${ }^{1,2}$

Miriam Orcutt, senior research fellow ${ }^{3}$

Larry Gostin, professor of global health law l.5 $^{4,5}$ 
Christy Adeola Braham, founder ${ }^{6,7}$

Patrick Duigan, regional migration health adviser ${ }^{8}$

${ }^{1}$ African Centre for Migration and Society, University of the Witwatersrand, Johannesburg, Gauteng, South Africa

${ }^{2}$ Centre of African Studies, University of Edinburgh, Edinburgh, UK

${ }^{3}$ Institute for Global Health, University College London, London, UK

${ }^{4}$ Georgetown University Center for Aphasia Research and Rehabilitation, Washington, DC, USA

${ }^{5}$ World Health Organization Collaborating Center on National and Global Health Law, Washington, USA

${ }^{6}$ African Platform for Migration and Inclusion in Health, London, UK

${ }^{7}$ University of Sheffield, Sheffield, UK

${ }^{8}$ International Organization for Migration, Regional Office for Asia and the Pacific, Bangkok, Thailand

Correspondence to: JVearey

jovearey@gmail.com

\section{(c) $)(1)$ O}

This is an Open Access article distributed in accordance with the Creative Commons Attribution Non Commercial (CC BY-NC 4.0) license, which permits others to distribute, remix, adapt, build upon this work non-commercially, and license their derivative works on different terms, provided the original work is properly cited and the use is non-commercial. See: http://creativecommons.org/ licenses/by-nc/4.0/.

\section{D) Check for updates}

1 Khan MS, Osei-Kofi A, Omar A, et al. Pathogens, prejudice, and politics: the role of the global health community in the European refugee crisis. Lancet Infect Dis 2016;16:e173-7. doi:10.1016/S14733099(16)30134-7

2 de Vries LA, Guild E. Seeking refuge in Europe: spaces of transit and the violence of migration management. J Ethn Migr Stud 2018. doi:10.1080/136918 3X.2018.1468308

3 Williams K, Mountz A. Between enforcement and precarity: externalization and migrant deaths at sea. Int Migr 2018;56:74-89. doi:10.1111/imig.12439
4 International Organization for Migration. Missing migrants project. https://missingmigrants.iom.int/.

5 Amnesty International. Between the devil and the deep blue sea. Europe fails refugees and migrants in the central Mediterranean. 2018. https://www. amnesty.org/en/documents/eur30/8906/2018/en/

6 International Organization for Migration. World migration report 2013: migrant well-being and development. IOM, 2013.

7 Wickramage K, Vearey J, Zwi AB, Robinson C, Knipper M. Migration and health: a global public health research priority. BMC Public Health 2018;18:987. doi:10.1186/s12889-018-5932-5

8 Hanefeld J, Vearey J, Lunt N, Researchers on migration, mobility and health group. A global research agenda on migration, mobility, and health. Lancet 2017;389:2358-9. doi:10.1016/S01406736(17)31588-X

9 Griswold KS, Pottie K, Kim I, Kim W, Lin L. Strengthening effective preventive services for refugee populations: toward communities of solution. Public Health Rev 2018;39:3. doi:10.1186/ S40985-018-0082-y

10 Krasnik A, Bhopal RS, Gruer L, Kumanyika SK. Advancing a unified, global effort to address health disadvantages associated with migration, ethnicity and race. Eur J Public Health 2018;28(suppl_1). doi:10.1093/eurpub/cky046

11 Abubakar I, Aldridge RW, Devakumar D, et al, UCL-Lancet Commission on Migration and Health. The UCL-Lancet Commission on Migration and Health: the health of a world on the move. Lancet 2018;392:2606-54. doi:10.1016/S01406736(18)32114-7

12 United Nations. World population prospects: the 2017 revision, key findings and advance tables. Working paper No ESA/P/WP/248. UN Department of Economic and Social Affairs, Population Division, 2017. https://esa.un.org/unpd/wpp/Publications/ Files/WPP2017_KeyFindings.pdf.

13 Internal Displacement Monitoring Centre. Global report on internal displacement. 2017. http://www. internal-displacement.org/global-report/grid2017/ pdfs/2017-GRID.pdf

14 Sweileh WM, Wickramage K, Pottie K, et al. Bibliometric analysis of global migration health research in peer-reviewed literature (2000-2016). BMC Public Health 2018;18:777. doi:10.1186/ s12889-018-5689-x

15 Allen W, Anderson B, Van Hear N, et al. Who counts in crises? The new geopolitics of international migration and refugee governance. Geopolitics 2018;23:21743. doi:10.1080/14650045.2017.1327740
16 Horner J, Rule J. The politics of space and the spatialisation of politics: new directions for examining the connections between immigration and contagion. New Political Science 2013;35:463-78. doi:10.1080/07393148.2013.813699

17 Pugh S. A moving target. Gender, health and the securitisation of migration. In: O'Manique C, Fourie P, eds. Global health and security. Critical feminist perspectives. Routledge, 2018. https://www. taylorfrancis.com/books/e/9781317195580/chapt ers/10.4324\%2F9781315559568-5.

18 Mclnnes C, Lee K. Health, security and foreign policy. Rev Int Stud 2006;32:5-23. doi:10.1017/ S0260210506006905

19 Migration and health. Lancet Infect Dis 2016;16:867. doi:10.1016/S1473-3099(16)30218-3

20 Greenaway C, Castelli F. Infectious diseases at different stages of migration: an expert review. J Travel Med 2019;26:taz007. doi:10.1093/jtm/ taz007

21 International Organization for Migration. Health of migrants: resetting the agenda. Report of the 2nd Global Consultation. Colombo, Sri Lanka, 21-23 Feb 2017. 2017. https://www.iom.int/sites/default/files/ our work/DMM/Migration-Health/GC2 SriLanka Report_2017_FINAL_22.09.2017_Internet.pdf

22 Trummer U, Novak-Zezula S, Renner A, et al. 2.10-P10 Cost savings through timely treatment for irregular migrants and European Union citizens without insurance. Eur J Public Health 2018;28(Suppl1):cky048.061. doi:10.1093/ eurpub/cky048.061

23 Kickbusch I. Global health governance challenges 2016-are we ready? Int J Health Policy Manage 2016;5:349-53. doi:10.15171/ ijhpm.2016.27

24 World Health Organization. Health in All Policies (HiAP) framework for country action. WHO, 2014.

25 Vearey J, Hui C, Wickramage K. Migration and health. In: World migration report. International Organization for Migration (forthcoming).

26 Wickramage K, Mosca D, Peiris D, eds. Migration health research to advance evidence based policy and practice in Sri Lanka. Vol 1. International Organization for Migration, 2017.

27 Bennett B, Cohen IG, Davies SE, et al. Future-proofing global health: governance of priorities. Global Public Health 2018;13:519-27. doi:10.1080/17441692.2 017.1296172

Cite this as: BMJ 2019;366:14143

http://dx.doi.org/10.1136/bmj.l4143 